\title{
Changing Curriculum Practice in Early Childhood Education Setting: An Action Research to Enhance Authentic Assessment
}

\author{
Faridah Yunus, PhD \\ Department of Education and Community Wellbeing \\ Faculty of Education, Universiti Kebangsaan Malaysia
}

\begin{abstract}
The goal of Early childhood education (ECE) is to provide environment to support children's holistic development. Therefore, curriculum and assessment must be planned carefully to encourage activities that could nurture the development. This paper discusses the reflexive accounts of the author based on her experience, as an academician/researcher transforming an early childhood education practice in local context. The transformation from paper-and-pencil (P-P) activities/tests towards authentic curriculum and assessment practice was carried out as a democratic process guided by action research design. A catalyst in the form of Curriculum-Based Assessment (CBA) instrument was used to guide the author. There were four parts involved which are modification of (i) lesson plan, (ii) physical and social environment, (iii) children's activities, (iv) assessment. These modifications were carried out throughout the one-year teacher training period. By applying reflexive technique to change the practice i.e. democratic approach, the training plans/syllabus had to be modified by alternating discussion with hands-on activities with the teachers. Data showed that changes in the physical settings and social atmosphere had led to a more responsive relationship between teachers and children. Hence, more criteria of development were nurtured than previously observed when children's activities were focused on the P-P. These can be seen in the recorded photos, videos and work samples recorded in the children's portfolio. Lack of academic qualifications and continuous trainings among the teachers posed a great challenge for the change to take place.
\end{abstract}

Keywords: Early childhood education, curriculum, assessment, action research, reflexive, child development

\section{INTRODUCTION}

Assessment is key to understanding a child's development, from which, teacher/caregiver can (re)arrange the teaching \& learning (T-L) i.e. curriculum which includes the environment both physical and social, to cater for individual needs. The lack of systematic blueprint available to directly implement curriculum that would encourage holistic development in ECE setting as observed in the context, meant that children's developmental progress is left to chance (Faridah Yunus 2013; 2014). Action research, a reflexive, collaborative and democratic in approach (MacNaughton and Hughes 2009) design was utilized to assist the author in changing the T-L process. Curriculum-Based Assessment (CBA) also known as authentic assessment, which was selected as a catalyst during the modification of the T-L process, also requires for collaborations between stakeholders (Macy and Hoyt-Gonzales 2007) and adherence to the transdisciplinary approach. Changes in T-L in current study means changes in the spaces (physical and social) that encourage children's activities through which criteria of development can be observed naturally. 


\section{Operational Definition}

Curriculum in early childhood education comprises all activities that are concrete, sensorial, and socio-culturally relevant to the child's life in which holistic development of the child can be nurtured through effective physical and social environment.

Assessment is defined as an approach to collect and record data of development from various sources/media, through naturalistic observation, for adults to plan for individualized, and small or large-group teaching and learning processes.

Democratic approach is applied in action research design where the researcher reflects critically or being reflexive by constantly asking questions about his/her actions to avoid biasness in every aspect of the decision-making process for actions to be fair.

\section{Developmental domains}

\section{THEORETICAL FRAMEWORK}

Developmental domains can be classified into physical/perceptual, cognitive/language, and psycho-social (Berk 2009; Bee 2007; Papalia et al. 2006). These domains need to be nurtured simultaneously to ensure optimum growth and curriculum that are based on these principles also encourage appropriate spaces be provided to enhance learning (Essa and Rogers 1992). Play is an activity that is highly recommended by experts in various disciplines from developmental science to education, to develop these domains. (Wood and Attfield 2005; Waller 2009a; Anning 2005; Smith 2010). Post-modernists reject views that are too rigid and in fact, claim that knowledge must be developed together, socially and with justice (Atkinson 2009). Human diversity in all aspects must be given prior attention when developing curriculum Cole (2005); Gonzalez-Mena (2005); Robinson dan Diaz (2006); Papatheodorou dan Moyles (2012) and hence, assessment tool to ensure fairness as stated in the UNCRC (UNICEF 2001).

\section{Intellectual disposition versus academic abilities}

Gardner (1993) defines intelligence as the abilities to solve problems and that solving problems requires high-level reasoning skills also known as the high cognitive capacity. To achieve high-level of cognitive ability, a learner needs to acquire learning disposition (Helm dan Katz 2001; Brooker 2011). Intellectual disposition can be interpreted as the tendency to investigate, search for evidence, infer, analyse, find the truth, look for accuracy, and the causeeffect about problems. All these characteristics are in contrast with the academic abilities that dominate the teaching and learning process in schools (Weeden et al. 2002; Katz dan Helm 2001; Harlen 2007). Academic abilities are components of knowledge and skills that are arranged rigidly and taught directly to learners which are also known as syllabus. Important aspect of academic world is formal P-P tests from which process, students are labelled according to their performances. This approach cannot guarantee i) future success, ii) future socio-economic status, and iii) meaningful and engaging learning experience (Cannella dan Viruru 2004).

\section{Curriculum and Assessment Cycle}

Authentic assessment instrument applied in this study is known as Assessment, Evaluation and Programming Systems (AEPS ${ }^{\circledR}$ ). It is a Curriculum-Based Assessment (CBA) where its use is mainly to LINK (Bagnato et al. 2010) the criteria in the assessment tool back to its curriculum. In other words, where curriculum contains syllabus, assessment usually contains items and in this CBA case its items are replaced by criteria (see figure 1). AEPS is highly recommended in inclusive settings because of its LINKing property which means the intervention process would be smoothly transferred from the diagnostic criteria to the activities. AEPS has six domains 
which are fine motor, gross motor, adaptive, cognitive, social and socio-communication (Bricker et al. 2002; Grisham-Brown dan Pretti-Frontczak 2006).

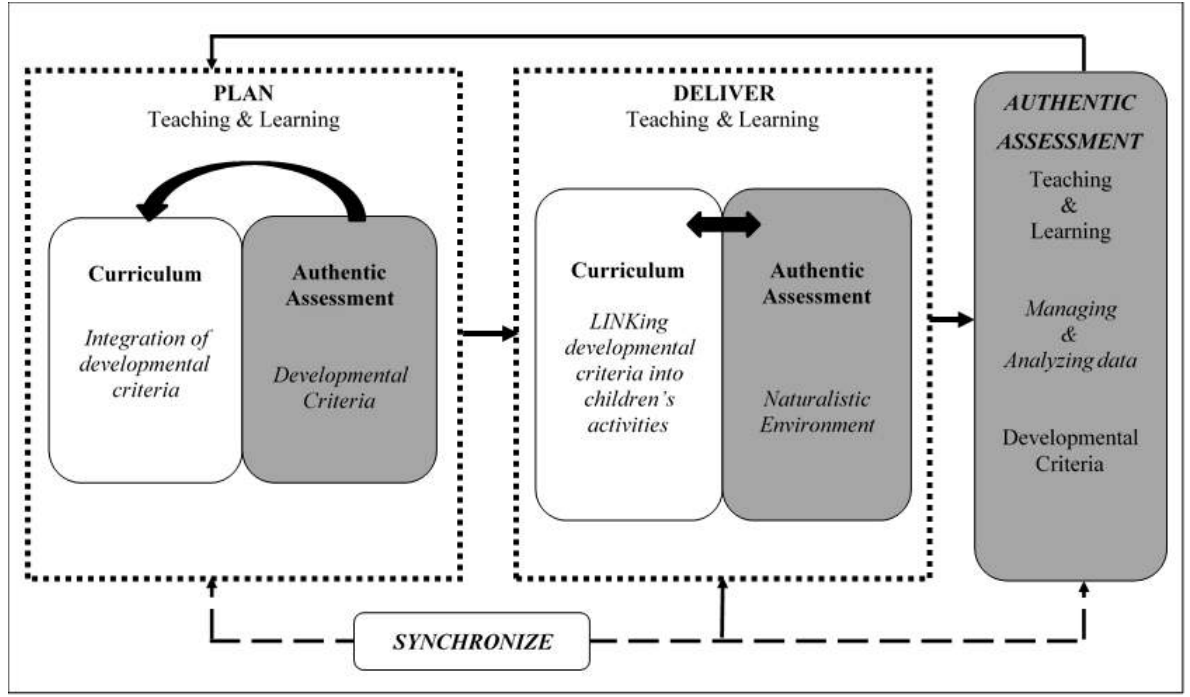

Figure 1. The curriculum-assessment cycle

\section{Learning spaces and children's activities}

Bricker et al. (2002) suggest that activities for children to be created in activity spaces as listed in Table 1. The authors also recommended that these spaces and the activities be mapped to the developmental criteria to ensure holistic developmental opportunity. This can also serve as a method to apply naturalistic observation for assessment purposes which is not discussed here.

Table 1. Space, activity and developmental criteria mapping recommended by AEPS ${ }^{\circledR}: 3-6$

\begin{tabular}{|c|c|c|c|}
\hline No. & Space & Activity & Developmental Criteria \\
\hline 1 & Art & Sketching, drawing, craft, writing & Fine motor: SA, SB \\
\hline 2 & Dressing up & Putting on clothes, buttoning shirt & $\begin{array}{l}\text { Adaptive: SC } \\
\text { Cognitive: SF }\end{array}$ \\
\hline 3 & Manipulative & Play with beads, marbles, LEGO, puzzle & Socio-communication: SA \\
\hline 4 & Recreational & Cycling, playing ball, games & $\begin{array}{l}\text { Gross motor: SA, SB } \\
\text { Cognitive: SF } \\
\text { Social: SA }\end{array}$ \\
\hline 5 & Bathroom/toilet & shower, cleaning face, using toilet, & Adaptive: SB, SC \\
\hline 6 & Outdoor/courtyard & $\begin{array}{l}\text { balancing, thug-and-war, running, } \\
\text { climbing stairs }\end{array}$ & $\begin{array}{l}\text { Cognitive: SA, SC } \\
\text { Adaptive: SA, SC } \\
\text { Gross motor: SA, SB } \\
\text { Socio-communication: SA }\end{array}$ \\
\hline 7 & Kitchen/pantry & $\begin{array}{l}\text { baking, cooking, cutting, smashing, } \\
\text { chopping, rolling, kneading }\end{array}$ & $\begin{array}{l}\text { Social: SA, SB } \\
\text { Social: SA, SB, SD } \\
\text { Cognitive: SA, SB, SC, SE, SG } \\
\text { Fine motor: RA } \\
\text { Socio-communication: SA }\end{array}$ \\
\hline 8 & Reading/storybook corner & reading, relaxing and sharing stories & $\begin{array}{l}\text { Social: SB, SC, SD } \\
\text { Cognitive: SA, SC, SE, SH }\end{array}$ \\
\hline 9 & Post office & sending parcel, buying/selling & $\begin{array}{l}\text { Social: SA, SB, SD } \\
\text { Cognitive: SA, SC, SD, SE, SF, SH } \\
\text { Fine motor: SA, SB } \\
\text { Socio-communication: SA }\end{array}$ \\
\hline
\end{tabular}

\section{Criteria for developmental domains}

Note: $S A=$ Strand $A$

There are six domains of development in AEPS ${ }^{\circledR}: 3-6$ which are fine motor, gross motor, adaptive, cognitive, socio-communication, and social. Each domain has a few Strands which 
divides skills into categories. In each Strand, there are a few Goals and in each Goal, there are a few Objectives. Criteria for Goals and Objectives are explained in detail with examples of activities which can be found in the four volumes of the document. There are 21 Strands, 54 Goals, and 163 Objectives (see Table 2). All Goals and Objectives of 217 criteria were to be applied in the T-L process by embedding them into the activities which were expected to be observed in the activity spaces in the setting being studied.

Table 2. List of AEPS ${ }^{\circledR}: 3-6$ Strand, Goal, Objective for Developmental Domain

\begin{tabular}{|c|c|c|c|c|}
\hline Domain & Strand(S) & Goal(G) & Objective(0) & Total $(G+0)$ \\
\hline Fine Motor & 2 & 5 & 10 & 15 \\
\hline Gross Motor & 2 & 6 & 11 & 17 \\
\hline Adaptive & 3 & 7 & 28 & 35 \\
\hline Cognitive & 8 & 17 & 37 & 54 \\
\hline $\begin{array}{l}\text { Socio- } \\
\text { communication }\end{array}$ & 2 & 8 & 41 & 49 \\
\hline Social & 4 & 11 & 36 & 47 \\
\hline Sub-total & 21 & 54 & 163 & 217 \\
\hline Total $(\mathrm{S}+\mathrm{G}+\mathbf{0})$ & 238 & & & \\
\hline
\end{tabular}

\section{Teacher training}

The teachers were trained on how to write lesson plans, create learning spaces, plan children's activities and record the T-L processes for assessment. Six teachers spent almost 100 hours for the training which took about a year to complete. Whilst the training was on-going, teachers made the modifications to the T-L process. Critical reflection techniques were applied during the train-modify actions, and thus the changes were expected to stem from the teachers' willingness to change because they believe in it - otherwise it would have been a top-down, autocratic approach.

\section{PROBLEM STATEMENT}

The problem arose in the social context where a holistic developmental approach to education intended for young children aged between 3-6 years was deemed not fully applied or applied at minimal level. The problem became more critical when the practice had not had the National Curriculum as its core guide. The teachers, like many other practitioners, knew only one way to teach - using books, worksheets, tests and very little of play-based activities. Using Curriculum-based Assessment (CBA) instrument could assist not only in implementing the assessment but also the curriculum because the two (curriculum and assessment) needed to go hand in hand. By laying out the foundation of curriculum and assessment for the teachers to start with, this study aimed to persuade teachers to change their practice towards more developmentally and culturally appropriate.

\section{RESEARCH OBJECTIVES}

The aim of this study was to change the T-L approach towards more holistic approach that involved sensorial-based and multi-domain activities so that assessment could be carried out through naturalistic observation to record more reliable data.

\section{METHODOLOGY}

Critical reflection or reflexive was the backbone of the process of implementation; which was embedded in the action research design (MacNaughton and Hughes 2009). Post-modernism perspective of action research is a paradigm underlying the work where research process was flexible, emerging and engaging (Brown and Jones 2001). AEPS ${ }^{\circledR}$ was used a catalyst to initiate the change and reflexive methodology directed the cycles to be emerging. The cycles took almost a year to complete; six preschool teachers, about sixty pre-schoolers, six expert panel 
from the hospital-based centre, and six semi-professional and professional observers participated in the study.

There were three sources (see figure 2) that had guided the research process which was first, action research cycle of four phases; second, research methodology for young children, reflexive approach, and authentic assessment approach; and the third, was curriculum-based instrument $\mathrm{AEPS}^{\circledR}$. These layers were intertwined and with no distinguish boundaries; and they rooted from various field or expertise namely developmental science, education, special education, medical/paediatric and neuropsychology.

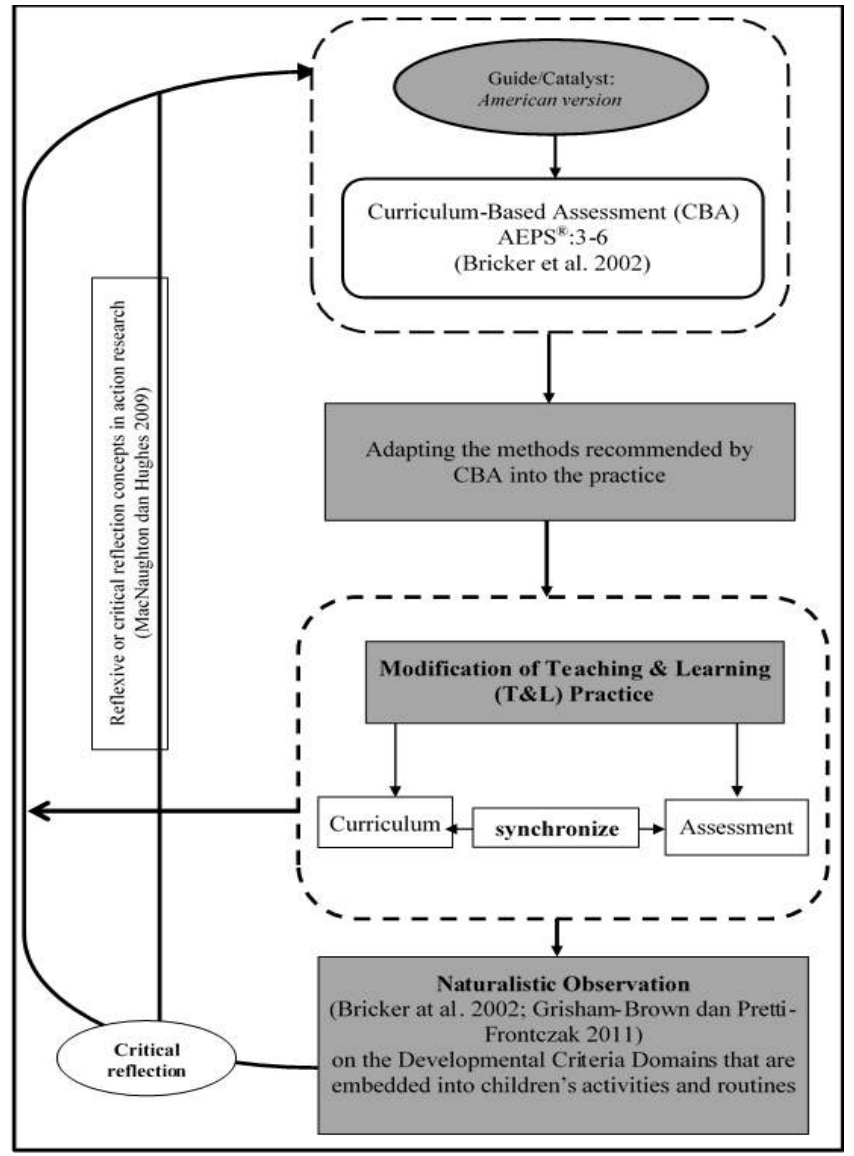

Figure 2. The research design for changing curriculum and assessment practice (adapted from Faridah Yunus 2013)

\section{PROCESSES AND FINDINGS}

The purpose was to change T-L practice which started with formal training and with the reflexive method, the training became less formal and had to be combined with hands-on activities. The hard part of the changing process was to change the social environment - that is to reduce the amount of direct instruction and policing among teachers. It was rooted in the social cultural context where the teachers grew up and/or live. Culturally speaking, Malay ethnic tends to obey the adults most of the time and it is considered rude when young people refuse to do so. Moreover, it is believed to be a sinful act for Malay-Muslim to disobey adults. Nonetheless, they are some Muslim scholars who believe that children should be treated otherwise - children must be loved with tenderness. As a result, teachers tend to be a little autocratic when they are at pre(school) simply because they choose to believe the former teachings. 
When teachers were given a set of questionnaires, most of them agree that trainings had made them more knowledgeable and skilled than before (Faridah Yunus 2013). Visible changes were recorded in the physical arrangement and children's activities; less of P-P and more of concrete, and sensorial-based activities. The journey to change the practice was of emotional roller-coaster for the parties involved. Changing the minds of the practitioners took more than just a series of lecture-based trainings. Since the lack of qualifications among the practitioners, the author had to literally sit down with them and slowly trying to make both sides understand the existing understanding of their own practice. When reflection took place during conversations with the teachers, then only trainings got more hands-on. Teachers needed constant guide and reminder; and the author needed to be there, just for them to ask questions, was a crucial exercise in ensuring change. Lack of knowledge and skills were observed as challenges that could be overcome through continuous professional development. This also had a challenge coming from lack of funding which was the result of low-fee service orientation - the results of perceptions of many individuals who think that education for young children is trivial.

\section{PART 1}

\section{Modification of the Curriculum Approach - From Subject-Based to Thematic-Project}

The modification of the curriculum started with changing the lesson plan. As observed, teachers used timetable that divided subjects like Mathematics, Language and Science into 3040-minute blocks. Children were taught via direct teaching method and they were required to complete the exercise books /worksheets. Teachers usually used blackboard/whiteboard to write out instructions. The scenario looked very much like at formal schools' classroom except for the audience who were much smaller than actual school pupils. By applying reflexive approach, the author had collaborated with teachers to modify the lesson plan by allowing more flexible hours for theme-based activities to be arranged into the timetable. Themes were chosen to assist teachers in planning activities because the author considered it as one of the basic approaches for novice teachers. Themes were selected and arranged into the yearly planner by teachers and subjects were taken out from the timetable and replaced with themebased activities. There were five themes planned which were Myself, Animals \& Insects, Plants \& Fruits, Transportation, and Community in Malaysia.

Various teaching techniques were introduced like demonstration, modelling, experiment, roleplay, and story-telling. These techniques reduced the occurrences of teachers' instructing children directly on what to do on what page of exercise books, and instead, increased the frequency in which teachers engaged in more exciting planning activities like planning for a visit, designing a science project, and gathering children's work for display. It was a daunting experience for teachers at the beginning when they had to plan the lesson. To ease the situation, the author had assisted the teachers by applying brainstorming method coupled with mind mapping techniques. First, teachers were asked to jot down all possible words that they could relate the theme. Then, they were asked to categorize the words into groups of their own choice. Table 3 shows the themes and sub-themes that were produced by the teachers. 
Table 3. The themes which were the guide for lesson planning

\begin{tabular}{|c|c|c|}
\hline Theme & Sub-theme & Duration \\
\hline Myself & $\begin{array}{l}\text { My Name; My Body; My Feelings; My Family; My Home; } \\
\text { My Neighbour; My Friend; My Hobby; My Favourite } \\
\text { Game; My Pet; My hometown }\end{array}$ & 2 months \\
\hline Animals \& & Getting to Know the Animals; Categories of Animals; & 2 months \\
\hline Insects & $\begin{array}{l}\text { Poisonous/Dangerous Animals; Petting Animals; Animal } \\
\text { in Water/Air/Ground; Habitat; Insects }\end{array}$ & \\
\hline Plants \& Fruits & $\begin{array}{l}\text { Getting to Know the Plants; Parts of Plants; Growth; } \\
\text { Growing Plants; Getting to Know the Fruits; Taste, Size, } \\
\text { Shape, and Colour }\end{array}$ & 2 months \\
\hline Transportation & $\begin{array}{l}\text { Types and Categories of Vehicles; Vehicles on the Road, } \\
\text { in the Water, and on Air; Shape, Size, Colour; Functions } \\
\text { and Use }\end{array}$ & 2 months \\
\hline $\begin{array}{l}\text { Community in } \\
\text { Malaysia }\end{array}$ & $\begin{array}{l}\text { Race. Ethnic, Religion; Celebrations; Attire; Food; } \\
\text { Customs; } \\
\text { Diversity }\end{array}$ & 2 months \\
\hline
\end{tabular}

\section{PART 2}

Modification of the physical and social environment - From classroom to learning spaces The arrangement of the spaces before the change took place looked very much like any classroom in formal school. Desks and chairs were arranged in rows and children faced teachers at the front; while teachers most likely to stand in front of a whiteboard either writing on it or giving instructions mostly related to academic activities. During the intervention, the author worked with the teachers to rearrange the furniture into "spaces" that could be accessed by children easily. Rooms that were left unattended or without specific functions were upgraded by identifying their functions and by adding appropriate materials (see table 4). 
Table 4. Functions of rooms before and after the change/intervention

\begin{tabular}{|c|c|}
\hline Before intervention & After intervention \\
\hline $1-6$ year old classroom & $1-6$ years' flexible space \\
\hline 2 - no specific function & 2 - Religious/Quranic study \\
\hline 3 - no specific function & 3 - Science \\
\hline $4-$ no specific function & 4 - Cooking \& Sewing \\
\hline 5 - no specific function & 5 - Drama \& Music \\
\hline $6-$ no specific function & 6 - Gardening \\
\hline 7 - shower /toilet & 7 - Resource/stationery room \\
\hline 8 - no specific function & 8 - Art 7 craft \\
\hline 9 - no specific function & 9 - Shower /toilet \\
\hline 10 - no specific function & 10 - Shop (pretend play) \\
\hline 11 - 5 year old classroom & 11 - Foyer /free play \\
\hline 12 - no specific function & 12 - Nap are (5 \& 6 years old) \\
\hline 13 - no specific function & 13 - Sports equipment \\
\hline 14 - teachers' room & 14 - Prayer room \\
\hline 15 - dining room & 15 - 5 years' flexible space \\
\hline \multirow[t]{6}{*}{16 - 4 year old classroom } & 16 - 4 years' flexible space \\
\hline & 17 - House/hut (pretend play) \\
\hline & 18 - Small playground \\
\hline & 19 - Dining room \\
\hline & 20 - Netball court \\
\hline & 21 - Large playground \\
\hline
\end{tabular}

Once spaces were being introduced, the rooms looked more welcoming and inviting; the interior felt softer and more relaxed. Children seemed to enjoy doing activities because it felt home-like environment as compared to the rigid classroom previously encountered. Desks and chairs were made available but were not strictly arranged nor the children were made to sit still behind desks. Figure 3 shows the open space environment.

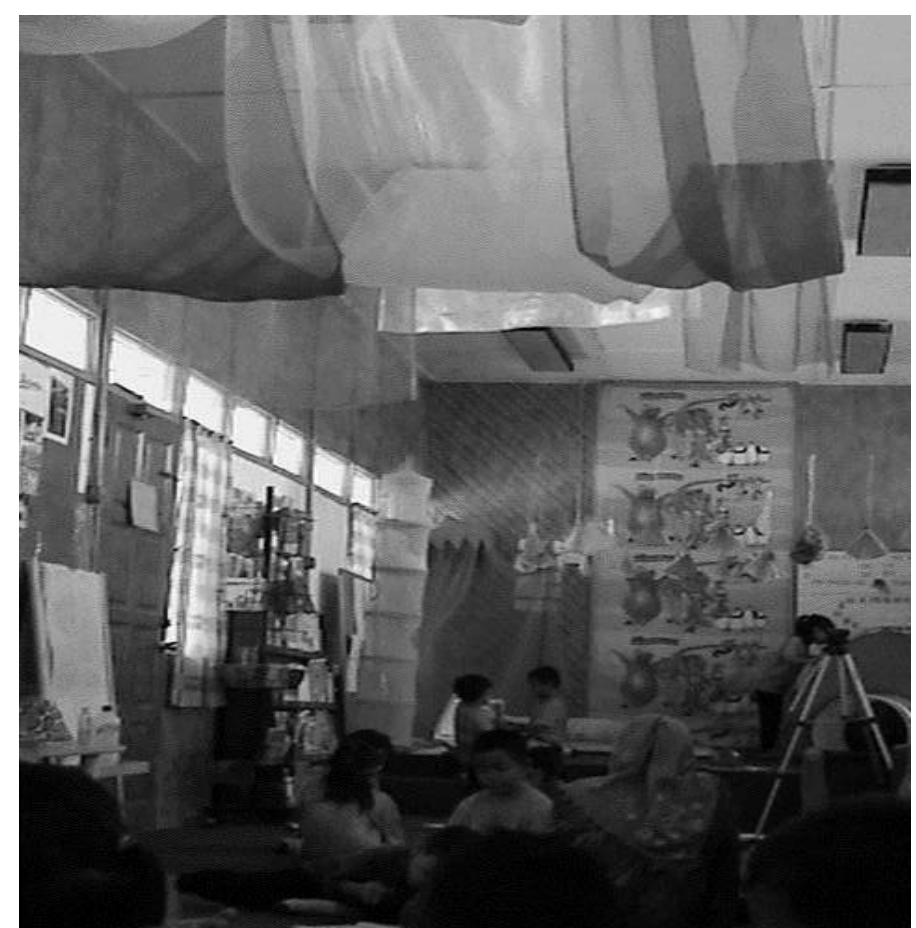

Figure 3. Open space arrangement of the physical setting to encourage flexible approach 


\section{PART 3}

\section{Modification of the children's activities - From paper-and pencil to sensorial and} concrete-based activities

Children's activities were planned around the themes and each theme had various activities from reading, drawing, painting, gardening, cooking to field trips. During the planning of activities, teachers were advised to ensure that they provide opportunities for more hands-on experience than teach-and-direct instructions; which includes sensory, experiential, concrete, and contextual elements. Figure 4 and 5 show the activities which were taken from two themes.

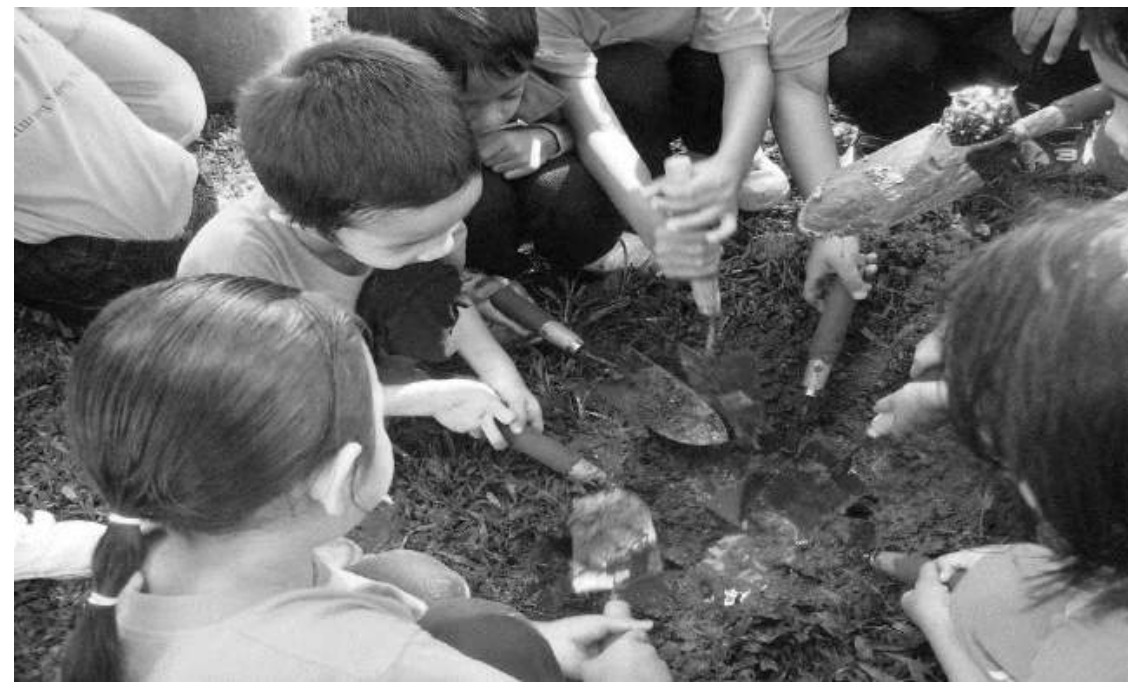

Figure 4. The activities which allows sensorial, concrete and contextual learning (Plants \& Fruits Theme)

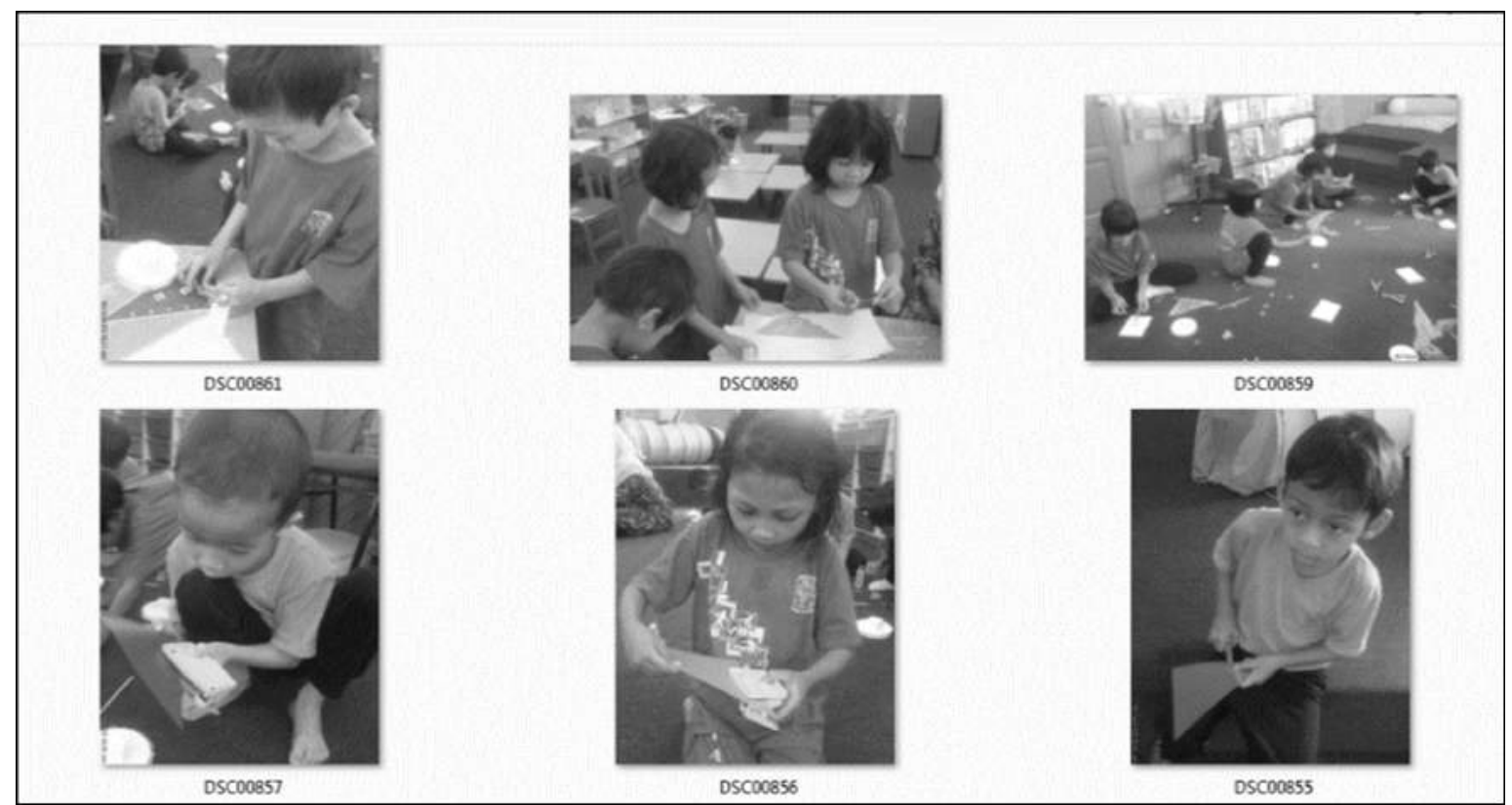

Figure 5. The activities which allows sensorial, concrete and contextual learning (Transportation Theme) 


\section{Modification of assessment approach - From grades to Portfolio}

Grades such as A, B, C, D and E were the main criteria used to assess children's performances in academic subjects like Mathematics, Language, and Science. Young children's developmental domains like socio-emotional, socio-communication, adaptive and cognitive were not the target of the existing preschool curriculum. When the change had begun, teachers were trained to know these criteria of developmental, to observe and to collect data for assessment purposes. Portfolio for each child was prepared by teachers and children's activities that capture their development were collected and recorded in various media format like checklist, photo, video, and work sample. However, in current studies teachers were not yet trained on how to assess the criteria using standardized developmental assessment instruments i.e. CBA. Teachers used these data to share with family about the child's progress or developmental and all activities that the child had accomplished during parent-teacher meetings which were held three times a year. Surprisingly, even though no grades were presented to family/parent, teachers received almost no complaint (Faridah Yunus 2013) whatsoever because parents thought they were fully informed of their child's activities and accomplishment. It was a huge relief to the research team led by the author as this was the first attempt to change practice that received fees from parents/family - clients might refuse to accept the change if they were unsatisfied with the change.
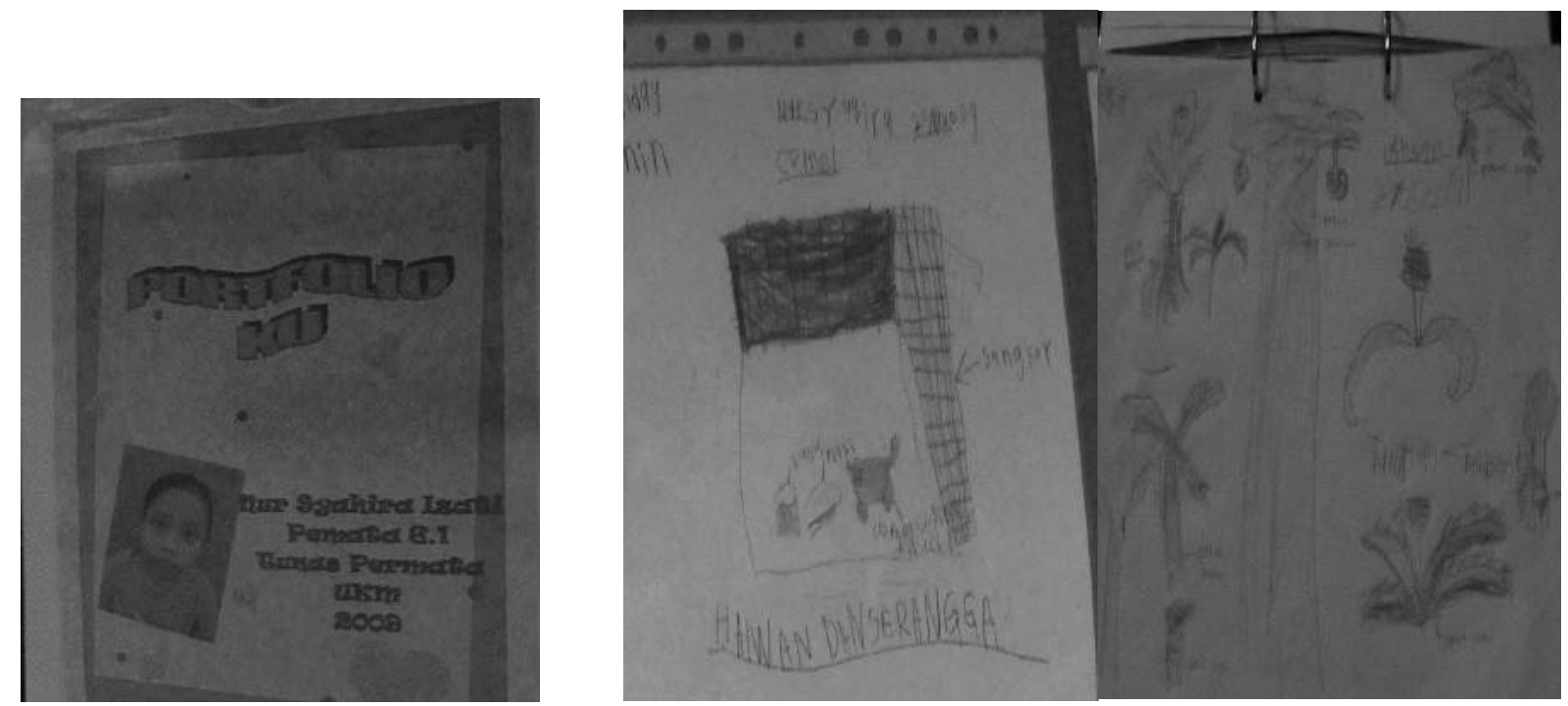

Figure 6. Children's portfolio which replaced grade-based progress report

\section{DISCUSSION}

\section{Holistic Development versus Academic Orientation}

Before the modification began, the T-L approach was academic in orientation; utilized subjectbased schedule, worksheet/ exercise books, and paper-and-pencil tests. Children's progress report which displays grades like $\mathrm{A}, \mathrm{B}, \mathrm{C}, \mathrm{D}$ and $\mathrm{E}$ was the main method to share with family. This kind of approach is inappropriate for holistic development of young children because it lacks sensorial, concrete, and hands-on experience opportunity. Table 5 shows the outcome of the current study - when more well-defined spaces were introduced, more activities could be planned and that more criteria of development could be observed occurring naturally.

Theories of development which has been dominated by western culture/ context, needs to be cautiously applied in local context of the current study. Post-modernism, feminism, poststructuralism, and post-colonialism allow researchers to view child's development from the 
cultural perspective; not universally consistent but culturally relevant (Cannella 2005; Cannella and Viruru 2004). Theories of development can no longer be considered as an objective and universal but must be considered from specific context such as culture (Cannella 2005; Walsh 2005; Cole 2005). Cultural psychology suggests that developmental psychology (Cole 2005) be reconstructed, thus more culturally appropriate curriculum design for young children can be developed.

\section{Table 5. Mapping of Children's Activity, Activity Spaces and Domains of Developmental After} Modification of T\&L

\begin{tabular}{|c|c|c|c|}
\hline No. & Name of space & Activity observed by researcher & Domain of development \\
\hline 1 & $\begin{array}{l}\text { Learning Year } \\
\text { 6/Manipulative } \\
\text { /Relax }\end{array}$ & $\begin{array}{l}\text { Writing, arithmetic, reading, } \\
\text { sketching, drawing, painting, crafting, } \\
\text { cutting, singing, morning circle, } \\
\text { pasting, labelling, poetry reading, } \\
\text { story-telling, arranging, organizing, } \\
\text { paying with manipulatives, soft toys, } \\
\text { making model. }\end{array}$ & $\begin{array}{l}\text { a. Fine motor: All criteria } \\
\text { b. Cognitive: All criteria } \\
\text { c. Socio-communication: SA G1 } \\
\text { d. Social: All criteria }\end{array}$ \\
\hline 4 & $\begin{array}{l}\text { Sewing \& } \\
\text { Cooking }\end{array}$ & $\begin{array}{l}\text { Cutting, blending, grinding, weighing, } \\
\text { measuring, baking, mixing, scooping, } \\
\text { stirring, washing. }\end{array}$ & $\begin{array}{l}\text { a. Fine motor: SA G1, SA G1 } 01.1 \\
\text { b. Cognitive: SC G1, SC G1 } 01.1 \\
\text { c. Socio-communication: All criteria except Strand B } \\
\text { d. Social: All criteria except Strand D Goal } 3\end{array}$ \\
\hline 6 & Gardening & $\begin{array}{l}\text { Planting, digging, watering plants, } \\
\text { observing and recording the plants. }\end{array}$ & $\begin{array}{l}\text { a. Fine motor: SA G1, SA G1 01.1 } \\
\text { b. Cognitive: SC G1, SC G1 01.1, SE G1, SE G1 01.1, SE G1 01.2, } \\
\text { SE G2, } \\
\text { Strand B } \\
\text { d. Social: All criteria } \\
\text { a Fine motor: SA G1, SA G1 } 01.1\end{array}$ \\
\hline 8 & Art & $\begin{array}{l}\text { Painting, sketching, collage making, } \\
\text { pattern-making, washing, crafting. }\end{array}$ & $\begin{array}{l}\text { b. Cognitive: SA G1, SA G1 01.1, SA G1 01.2, SA G1 } 01.3 \\
\text { c. Socio-communication: All criteria except Strand B } \\
\text { d. Social: All criteria Strand B dan C }\end{array}$ \\
\hline 9 & Shower/toilet & $\begin{array}{l}\text { Using toilet, showering, undressing, } \\
\text { dressing up. }\end{array}$ & a. Adaptive: All criteria Strand B dan C \\
\hline 10 & Shop & $\begin{array}{l}\text { Role playing, selling, buying, } \\
\text { counting, choosing products. }\end{array}$ & $\begin{array}{l}\text { a. Fine motor: SA G1, SA G1 } 01.1 \\
\text { b. Socio-communication: All criteria except Strand B } \\
\text { c. Social: All criteria }\end{array}$ \\
\hline 11 & Foyer & $\begin{array}{l}\text { Physical exercise, singing/praying, } \\
\text { event celebration, morning assembly, } \\
\text { sharing stories, free play, playing } \\
\text { with balls (kicking, throwing, } \\
\text { catching), traditional games. }\end{array}$ & $\begin{array}{l}\text { a. Fine motor: SA G1, SA G1 } 01.1 \\
\text { b. Gross motor: All criteria except SA G2 dan SA G2 } 02.1 \\
\text { c. Cognitive: All Strand F } \\
\text { d. Socio-communication: All criteria except Strand B } \\
\text { e. Social: All criteria }\end{array}$ \\
\hline 15 & $\begin{array}{l}\text { Learning Year } \\
\text { 5/Manipulative } \\
\text { /Relax }\end{array}$ & $\begin{array}{l}\text { Writing, arithmetic, reading, } \\
\text { sketching, drawing, painting, crafting, } \\
\text { cutting, singing, morning circle, } \\
\text { pasting, labelling, poetry reading, } \\
\text { story-telling, arranging, organizing, } \\
\text { paying with manipulatives, soft toys, } \\
\text { making model. }\end{array}$ & $\begin{array}{l}\text { a. Fine motor: All criteria } \\
\text { b. Cognitive: All criteria } \\
\text { c. Socio-communication: SA G1 } \\
\text { d. Social: All criteria }\end{array}$ \\
\hline 16 & $\begin{array}{l}\text { Learning Year } \\
\text { 4/Manipulative } \\
\text { /Relax }\end{array}$ & $\begin{array}{l}\text { Writing, arithmetic, reading, } \\
\text { sketching, drawing, painting, crafting, } \\
\text { cutting, singing, morning circle, } \\
\text { pasting, labelling, poetry reading, } \\
\text { story-telling, arranging, organizing, } \\
\text { paying with manipulatives, soft toys, } \\
\text { making model. }\end{array}$ & $\begin{array}{l}\text { a. Fine motor: All criteria } \\
\text { b. Adaptive: All Strand C } \\
\text { c. Cognitive: All criteria } \\
\text { d. Socio-communication: SA G1 } \\
\text { e. Social: All criteria }\end{array}$ \\
\hline 17 & Hut/shades & Role playing, pretentious play. & $\begin{array}{l}\text { a. Fine motor: SA G1, SA G1 } 01.1 \\
\text { b. Socio-communication: SA G1 } \\
\text { c. Social: All criteria }\end{array}$ \\
\hline 18 & Playground & Climbing, sliding, swinging, free play. & $\begin{array}{l}\text { a. Gross motor: SA G2, SA G2 02.1, SB G1, SB G1 01.1, SB G1 } \\
01.2 \text {, SB G1 01.3 } \\
\text { b. Cognitive: SF G2, SF G2 02.1, SF G2 } 02.2 \\
\text { c. Social: All criteria }\end{array}$ \\
\hline
\end{tabular}


Standardized tests are widely used in some developed nations and in the United States, these tests are also known as 'school readiness' measurements (Meisels 2007). However, this kind of practice are being criticized when its use impedes the teachers' ability to be creative and flexible in the T-L process (Crain 2005). In Malaysia, Early Childhood Education faces similar quality dilemma or challenges (Rohaty 2003). Seefeldt (2005) suggested that standard could improve curriculum if the system relies upon i) valid research and theory, ii) content are wider and not restricted to academic skills, iii) realistic expectations from adults, and iv) contextual.

Human brain grows very rapidly during the first six years (Johnson 2005; Keenan dan Evans 2009; Talay-Ongan 2005), therefore, the neurons must be stimulated in early years (Nutbrown 2006). Neuroscience research emphasizes that children's activities must be planned so that higher order thinking skills can be nurtured; by having exciting physical and safe social environment (Rushton et al. 2009; Rushton dan Juola-Rushton 2008; Rushton 2011).

Quality education for young children before formal schooling is crucial (Penn 2011; Nutbrown 2006) because it affects positive long-term growth (Brooker 2007) like reducing school dropout, delayed development and juvenile delinquencies (High /Scope 2009; Hendrick dan Weissman 2006). United States is one of the nations that measures ECE quality from the economic perspective as reported in Barnett dan Kelley (2006). Nonetheless, there are also suggestions that 'quality' in ECE should be considered away from economic measures, and instead children must be allowed to be the co-constructor of identity, culture and knowledge (Dahlberg, Moss dan Pence 1999). This is widely-known as the post-modernism view that emphasizes on the democratic approach like the one practiced in Reggio Emilia Approach (Rinaldi 1993).

Although there have been a few opinions and thoughts in ECE, but it remains very important system in society because positive environment will enhance the positive development of its young generation and thus, more harmonious society for the future. When children spend lesser time than they ought to with family members, due to various socio-economic factors, then nursery, preschool, and kindergarten play major roles to help nurture the development processes. Collaboration with stakeholders is key to achieve this (Bronfenbrenner 2005); to understand children within their context and to give a fair chance as individual human being as stated in the United Nation on the Rights of the Child (UNICEF 2001).

As a conclusion, no matter what the curriculum and/or the assessment practice are, children's holistic development must be monitored systematically in naturalistic environment to ensure long-term positive life (Nutbrown 2006; Brassard and Boehm 2007; Brassard and Boehm 2007; Wortham 2008; Salvia et al. 2010).

\section{FUTURE RESEARCH}

At the local context, emphasis must be given towards rearranging the physical and social environment to allow more flexible approach curriculum to take off. Research must focus on the establishing the developmental criteria; developing highly valid and reliable instruments; assessment procedures for diagnostic purposes; and mechanism for funding eligibility for children wo need extra assistance. Then, curriculum can be designed to cater the needs of individual child- typical and non-typical

\section{CONCLUSION}

Although grades do make impressions on lay people but developmental experts believe that infant, toddlers and pre-schoolers need to be nurtured in an environment that support the natural process. With this we mean that young children must be able to thrive safely without 
the pressure to score on paper, yet! Authentic assessment is a way to help educators design the environment to promote holistic development, and hence curriculum will be more developmentally and culturally appropriate.

\section{ACKNOWLEDGEMENTS}

An appreciation to the participants from various fields involved in the study whose invaluable first-hand experience dealing with young children has helped to complete the first round of authentic assessment journey.

\section{References}

Anning, A. (2005). Play and legislated curriculum. Back to basics: an alternative view. In Moyles, J. (Ed.). Ed. ke-2. The excellence of play. Berkshire: Open University Press.

Atkinson, E. (2007). The postmodern prism: fracturing certainty in educational research. In. Swann, J. \& Pratt, J. (Ed.) Educational research in practice. New York: Continuum.

Bagnato, S. J, Neisworth, J. T. \& Preti-Frontczak, K. 2010. LINKing Authentic Assessment \& Early Childhood Intervention: Best Measures for Best Practices. $2^{\text {nd }}$ Ed. Baltimore: Paul Brookes Publishing Co.

Berk, L. E. (2009). Child Development. Ed. ke-8. Boston: Pearson.

Bricker, D., Pretti-Frontczak, P., Johnson, J. \& Straka, E. (2002). Assessment, Evaluation, and programming system for infants and $c$ Macy, M. \& Hoyt-Gonzales, K. 2007 hildren: administration guide. Ed. ke-2. Ed. 1-4. Maryland: Paul H. Brookes Publishing Co., Inc.

Brown, T. \& Jones, L. (2001). Action research and postmodernism: congruence and critique. Buckingham: Open University Press.

Cole, M. (2005). In. Bornstein, M. H.\& Lamb, M. E. 2005. Developmental science: an advanced

Essa, Eva 1992. Early childhood curriculum from developmental model to application. Albany NY: Delmar Publishers.

Faridah Yunus. (2013). Pelaksanaan Penaksiran Autentik Dalam Konteks Pendidikan Awal Kanak-kanak: Satu kajian Tndakan. Tesis. Universiti kebangsaan Malaysia.

Faridah Yunus. (2014). Cross-cultural adaptation developmental criteria for young children: a preliminary psychometric study. International Education Sudies. Vol. 7, No. 13.

Faridah Yunus (2107). Transdisciplinary Authentic Assessment Approach in Early Childhood Education Setting: Processes and Challenges via Reflexive Methodology. (2017). Seminar for Transdisciplinary Education 2017. Universiti Kebangsaan Malaysia.

Gonzalez-Mena, J. (2005). Foundations of early childhood education: teaching children in a diverse society. Ed. ke-3. New York: Mc-Graw Hill.

Grisham-Brown, J. \& Pretti-Frontczak, K. (2011). Assessing young children in inclusive settings: the blended practices approach. Maryland: Paul H. Brookes Publishing Co.

Grisham-Brown, J., Hallam, R. \& Brookshire, R. (2006). Using authentic assessment to evidence children's progress toward early learning standards. Early childhood Education Journal 34(1): 45-51.

Helm, J. H. \& Katz, L. G. 2001. Young investigators: the project approach in the early years. New York: Teachers College Press.

MacNaughton, G. \& Hughes, P. (2009). Doing action research in early childhood studies. Berkshire: Open University Press.

Macy, M. \& Hoyt-Gonzales, K. (2007). A linked system approach to early special education eligibility assessment. Teaching Exceptional Children 39(3): 40-45.

Papalia, D. E., Olds, S. W. \& Feldman, R. D. (2006). A child's world. Ed. ke-10. New York: McGraw-Hill.

Papatheodorou, T. \& Moyles, J. (2012). Cross-cultural perspectives on early childhood. London: sage

Robinson, K. H. \& Diaz, C. J. (2006). Diversity and difference in early childhood education: issues for theory and practice. Berkshire: Open University Press. 
Smith, P. K. (2010). Children and play. West Sussex: Wiley-Blackwell.

UNICEF. (2001). Conventions on the right of the child. UNCRC. http://www.unicef.org/crc/ [01 Jun 2009 ].

Wood, E. \& Attfield, J. (2005). Play, learning and the early childhood curriculum. Ed. ke-2. London: Paul Chapman Publishing. 